\title{
Robert Jastrzębski
}

\section{Kodyfikacja i unifikacja polskiego prawa czekowego}

\begin{abstract}
Keywords: cheque (or check in American English); Polish Cheques Law; 1931 Geneva Conventions; cheque's functions; bill of exchange
\end{abstract}

\section{Summary}

The article presented deals with legal, economic and historical aspects of Polish cheques law.

The study is divided into five parts. Three of them concern a general issue of codification and unification of law in reborn Poland after the 1st World War, the international unification of cheques law, as well as they give an outline of form and nature of a cheque (or check in American English) as a type of bill of exchange, and depict various cheque's functions, such as payment, currency, guarnantee and credit ones. The fourth part comprise three sections: the state of cheques law at the first period of the Second Republic of Poland (1918-1924); the Polish cheques law - a decree passed by the President of the Republic of Poland (14th November 1924), and finally the Act of Cheques Law - a bill enacted by the Polish Parliament (28th April 1936). The activity of the Polish Commission of Codification is regarded as the most important for legislative results in this branch of law.

The attempt of international simplification and unification of law relating to cheques took place in Geneva (1931). On 19 March 1931 three conventions concerning this matter were signed: 1) the Convention providing a Uniform Law for Cheques (with two annexes and a protocol); 2) the Convention for the Settlement of Certain Conflicts of Laws in connection with Cheques (with a protocol); 3) the Convention on the Stamp Laws in connection with Cheques (and a protocol). Poland is of part these conventions and the Polish Cheques Law of April 28, since 1936 still is in force without essential changes, is consistent with these regulations. 


\section{Pojęcie kodyfikacji i unifikacji}

Kodyfikacja stanowi sensu largo stworzenie jednolitej, usystematyzowanej całości przepisów prawnych z określonej dziedziny prawa. Zwykle polega na nowelizacji, uproszczeniu, uzupełnieniu, a przede wszystkim na całkowitym bądź częściowym uchyleniu aktów prawnych lub przepisów dotychczas obowiązujących. W ten sposób wprowadzona zostaje w życie nowa regulacja prawna oparta zwykle na nowych zasadach, które realizują określony program prawno-polityczno-ekonomiczno-społeczny. Oczywiście pojęcie kodyfikacji często nie jest rozumiane jednolicie, zresztą sama nowożytna jej idea sięga okresu oświecenia ${ }^{1}$. Jednakże podana na wstępie bardzo ogólna definicja pozwala zrozumieć istotę kodyfikacji, a co za tym idzie odróżnić od terminu unifikacji, który często błędnie wprost jest z nią zamiennie używany.

Unifikacja bowiem stanowi ujednostajnienie (ujednolicenie) prawa przez wprowadzenie jednakowych uregulowań prawnych na obszarze państwa, także grupy państw. Dlatego w praktyce unifikacja dotyczy po prostu rozciągnięcia mocy obowiązującej określonej regulacji prawnej na część albo obszar jednego, niekiedy kilku państw. Warto zaznaczyć, że kodyfikacja zwykle jest utożsamiana z pojęciem kodeksu, czyli usystematyzowanego zbioru przepisów prawnych, z zakresu danej gałęzi prawa, np. cywilnego, karnego, handlowego, administracyjnego. Natomiast nie zawsze musi mieć taką postać, kodyfikacja bowiem może dotyczyć różnych dziedzin prawa. W związku z tym często stawia się znak równości między unifikacją a kodyfikacją, zwłaszcza w odniesieniu do prawa prywatnego II Rzeczypospolitej, m.in. wekslowego, czekowego, spółdzielczego, upadłościowego, układowego, składowego, zobowiązaniowego². Dlatego należy podkreślić, że kodyfikacja na pewno stanowi unifikację określonej gałęzi prawa. Natomiast sytuacja odwrotna nie zawsze ma miejsce. Po prostu kodyfikacja stanowi najwyższy poziom ujednolicenia i usystematyzowania określonej gałęzi prawa, a co za tym idzie dotyczy konkretnych działań legislacyjnych, których efektem końcowym jest stworzenie koherentnego aktu prawnego, często pod nazwą kodeksu.

1 Zob. K. Sójka-Zielińska, Wielkie kodyfikacje cywilne XIX wieku, Warszawa 1973; H. Izdebski, Kodyfikacje cywilne XX wieku, część I, Kodyfikacja jako instrument reformy prawa, „Czasopismo Prawno-Historyczne" (dalej: CPH) 1990, z. 1-2; L. Górnicki, Prawo cywilne w pracach Komisji Kodyfikacyjnej Rzeczypospolitej Polskiej w latach 1919-1939, Wrocław 2000, s. 60 i nast.

2 Zob. Z. Radwański, Prawo cywilne i proces cywilny, [w:] Historia Państwa i Prawa Polski 1918-1939, część II, red. F. Ryszka, pod ogólną red. J. Bardacha, Warszawa 1968; R. Jastrzębski, Na rozdrożach prawa wekslowego II Rzeczypospolitej, [w:] Wielokulturowość polskiego pogranicza. Ludzie - Idee - Prawo, red. A. Lityński, P. Fiedorczyk, Białystok 2003; R. Jastrzębski, Prawne regulacje funkcjonowania domów składowych w II Rzeczypospolitej, „Studia Iuridica”, t. 37 - Miscellanea, Warszawa 2000 . 
Z kodyfikacją i unifikacją prawa związana jest zwykle działalność określonych ciał kolegialnych, których zadaniem jest opracowanie takiego aktu prawnego. W historii prawa znanych jest wiele takich przypadków. Ograniczając się do prawa polskiego, okresu XX w., należy wymienić Komisję Kodyfikacyjną, działającą w II Rzeczypospolitej oraz po drugiej wojnie światowej ${ }^{3}$. W kodyfikacji i unifikacji prawa czekowego odegrała rolę komisja działająca w pierwszym $\mathrm{z}$ wymienionych okresów, powołana na podstawie ustawy z dnia 3 czerwca 1919 r. o Komisji Kodyfikacyjnej ${ }^{4}$. Należy zasygnalizować, że wpływ na polskie regulacje miały także międzynarodowe próby ujednostajnienia prawa czekowego, a ostatecznie trzy konwencje genewskie z lat 30., do których przystąpiło ówczesne państwo polskie.

Uwagi poczynione na temat kodyfikacji i unifikacji prawa mają na celu usystematyzować terminologię, a tym samym uporządkować przedpole dla dalszych rozważań. Oczywiście nie wyczerpują tematu, w tym sporów co do pojęcia zarówno istoty kodyfikacji jak i unifikacji. Pozwalają natomiast zrozumieć istotę tych działań legislacyjnych, których celem nadrzędnym jest ujednolicenie prawa. Na zakończenie warto zauważyć, iż współcześnie staje się coraz bardziej popularna tzw. dekodyfikacja, która polega generalnie na zastępowaniu, zwłaszcza $\mathrm{w}$ odniesieniu do prawa prywatnego, unormowań kodeksowych regulacjami o zróżnicowanym charakterze w postaci m.in. ustaw szczególnych, orzecznictwa sądowego ${ }^{5}$.

\section{Prawo czekowe i jego unifikacja międzynarodowa}

Przekazy pieniężne, które przypominają współczesną instytucję czeku, były wykorzystywane już w średniowieczu. Wówczas jednocześnie w obrocie znajdowały się przekazy płatne w określonym terminie - weksle oraz płatne za okaza-

3 Szerzej: S. Grodziski, Komisja Kodyfikacyjna Rzeczypospolitej Polskiej, CPH 1981, z. 1; A. Lityński, Wydział Karny Komisji Kodyfikacyjnej II Rzeczypospolitej. Dzieje prac nad częścia ogólna kodeksu karnego, Katowice 1991; L. Górnicki, op. cit.; W. Czachórski, Przebieg prac nad kodyfikacją prawa cywilnego PRL, „Studia Prawnicze” 1970, z. 26-27; Z. Radwański, Prawo cywilne PRL, CPH 1995 z. 1-2; A. Lityński, Pół wieku kodyfikacji prawa w Polsce (1919-1969). Wybrane zagadnienia, Tychy 2001; A. Lityński, Historia Prawa Polski Ludowej, Warszawa 2005.

4 Dz. U. Nr 44, poz. 315.

5 Zob. H. Izdebski, op. cit.; Z. Radwański, Założenia nowego kodeksu cywilnego, „Rejent” 2008, $\mathrm{nr}$ 2; T. Giaro, Prawo i historia prawa $w$ dobie globalizacji. Nowe rozdanie kart, [w:] Prawo $w$ dobie globalizacji, red. T. Giaro, Warszawa 2011; T. Giaro, Wykładnia bez kodeksu. Uwagi historyczne o normatywności interpretacji prawniczej, [w:] Teoria i praktyka wykładni prawa, red. P. Winczorek, Warszawa 2005; F. Longchamps de Brier, Wobec dekodyfikacji: tradycja romanistyczna i prawo kanoniczne, „Acta Universitatis Wratislaviensis” 3063, Prawo 305, Studia Historycznoprawne, Tom poświęcony pamięci prof. Edwarda Szymoszka, red. A. Konieczny, Wrocław 2008; P. Święcicka, Sinusoid of Legal History. Learning from Roman Law - a fascinating challenge for our (post) modernity, [w:] Turning Points and Break Lines. Jahrbuch Junge Rechtsgesichte 4, München 2009. 
niem - czeki ${ }^{6}$. Co ciekawe w XIV-XV w. polscy władcy wystawiali przekazy pieniężne na miasta, które były zobowiązane do zapłaty kontrybucjī. Oczywiście, czy tego rodzaju przekazy możemy współcześnie uznać za pierwociny instytucji czeku pozostaje sprawą dyskusyjną. Zresztą miejsce genezy czeku stanowiło i stanowi do chwili obecnej zagadnienie niewyjaśnione. Niektórzy uważali, że czek po raz pierwszy był wykorzystywany na obszarze dzisiejszej Belgii i Holandii. Inni natomiast uznali, iż ojczyzną czeku był Półwysep Apeniński albo Szkocja ${ }^{8}$.

Istotne znaczenie dla upowszechnienia czeku miał rozwój obrotów tym papierem wartościowym w krajach anglosaskich, zwłaszcza w Wielkiej Brytanii oraz Stanach Zjednoczonych Ameryki Północnej. Warto bowiem podkreślić, że w tych państwach instytucja czeku odgrywała i odgrywa do chwili obecnej ogromną rolę $\mathrm{w}$ tzw. obrotach bezgotówkowych, $\mathrm{z}$ którymi wiąże się działalność izb kompensacyjnych (rozrachunkowych), tzw. clearing house. Dlatego utarło się powiedzenie, że „Londyn nie posługuje się walutą funtową, lecz czekową", a etymologicznie termin czek najprawdopodobniej pochodzi od czasownika angielskiego oznaczającego w języku polskim kontrolowanie, sprawdzanie ${ }^{10}$, choć niektórzy, ze względu na trudności związane z realizacją zapłaty należności czekowej, w okresie II Rzeczypospolitej uważali, że pochodzi od polskiego czasownika - czekać ${ }^{11}$.

Pierwsze regulacje dotyczące prawa czekowego pochodzą z XIX w. Najstarsza została wydana w Holandii w 1838 r. Inne państwa dokonały tego już w drugiej połowie tego stulecia, m.in. Francja (1865 r.), Szwajcaria (1881 r.), Anglia i Włochy (1882 r.), Hiszpania (1885 r.), Rumunia (1887 r.), Portugalia (1888 r.), Dania i Norwegia (1897 r.), Szwecja (1898 r.), oraz na początku XX w. m.in.

6 Zob. R. Jastrzębski, Czek i jego funkcje w II Rzeczypospolitej, „Studia Iuridica”, t. 42 - Miscellanea, Warszawa 2003.

7 Szerzej: Z. W., Z historji czeku, „Gazeta Bankowa” 1936, nr 6; R. Taubenschlag, Skrypty dłużne z klauzula ,na zlecenie” $i$,na okaziciela” $w$ średniowiecznem prawie polskiem, „Czasopismo Prawnicze i Ekonomiczne" 1936.

8 Szerzej: F. Flamm, Rzecz o wekslach i czekach na tle międzynarodowym, Warszawa 1882, s. 489; J. Namitkiewicz, Czekowe prawo, [w:] Encyklopedja Podręczna Prawa Prywatnego, t. I, red. H. Konic, Bydgoszcz 1932, s. 141; J. Namitkiewicz, Podręcznik Prawa Handlowego, wekslowego, czekowego i upadłościowego, Warszawa 1927, s. 458-459; S. Janczewski, Prawo Handlowe, Wekslowe i Czekowe, Warszawa 1946 (reprint: Warszawa 1990), s. 492; A. Szpunar, Komentarz do prawa wekslowego i czekowego, Warszawa 1996, s. 245; A. Kostecki, Prawo czekowe, Kraków 1998, s. 7.

9 S. Punicki, Znaczenie obrotu czekowego, „Gazeta Bankowa” 1928, nr 3, s. 53; zob. D. Rakowicz, O czekach, czyli ułatwieniu interesu depozytowego przez assygnacye, Poznań 1876.

10 Od słowa angielskiego to check - sprawdzać, kontrolować, bądź francuskiego èchec - szach. Szerzej: J. Namitkiewicz, Podręcznik Prawa Handlowego, wekslowego, czekowego..., s. 458-459; S. Janczewski, op. cit., s. 492.

11 S. Punicki, op. cit., s. 53. 
Austria (1906 r.), Niemcy (1908 r.) ${ }^{12}$. W ten sposób instytucja czeku została unormowana $\mathrm{w}$ wielu ówczesnych państwach przez prawo pozytywne, a obrót czekowy odbywał się $\mathrm{w}$ ramach określonych regulacji prawnych. W związku z tym pozbawiony był przypadkowości, w tym liczenia się przez jego uczestników z panującymi zwyczajami.

Nowym problemem natomiast zaczęły być różnice w ustawodawstwach krajowych poszczególnych państw, które miały bezpośredni wpływ na międzynarodowy obrót gospodarczy, korzystający z tego surogatu pieniądza. Dlatego na początku XX w. miały miejsce próby międzynarodowej unifikacji prawa czekowego. W tym celu m.in. zebrała się w dniach 8-9 listopada 1907 r. w Budapeszcie konferencja, zwołana przez Związek Gospodarczy Środkowej Europy. Miała ona bezpośredni wpływ na prawo czekowe państw tej części kontynentu - austriackie, niemieckie oraz węgierskie ${ }^{13}$. Celowi międzynarodowego ujednolicenia prawa czekowego służyły również sformułowane na sesji londyńskiej International Law Association, tzw. siedem tez (tzw. London Rules), w zakresie m.in. klauzuli pokryciowej, konieczności prezentowania i datowania, zleceniowego charakteru, terminów prezentacji, bezwzględnej odwołalności oraz instytucji tzw. czeków krzyżowych (zakreślonych) ${ }^{14}$. Przed pierwszą wojną światową najważniejsze jednak znaczenie miała Konferencja Haska z 1912 r., która dotyczyła międzynarodowej unifikacji prawa wekslowego ${ }^{15}$. Natomiast w wyniku jej obrad nie doszło do uchwalenia projektu prawa czekowego, a jedynie zostały przyjęte rezolucje co do dalszego ujednostajnienia tego działu prawa ${ }^{16}$.

Następnie sprawa międzynarodowej unifikacji prawa czekowego została podjęta przez Ligę Narodów, która powołała specjalny komitet, obradujący w latach 1927-1928. Komitet opracował projekt przyszłego prawa czekowego, który stał się przedmiotem obrad międzynarodowej konferencji w Genewie w lutym i marcu 1931 r. Końcowym wynikiem jej obrad było uchwalenie oraz podpisanie przez większość państw - uczestników, trzech międzynarodowych konwencji w sprawie: jednolitej ustawy o czekach, regulacji kolizji w zakresie ustaw czekowych poszczególnych państw oraz opłaty stemplowej w zakresie czeków.

$\mathrm{W}$ ten sposób nastąpiło ujednolicenie prawa czekowego w skali międzynarodowej, przy czym dotyczyło ono państw, które przystąpiły i ratyfikowały kon-

12 Szerzej: F. Flamm, op. cit., s. 491 i nast.; M. Kuratow, Zasady ustaw czekowych, Warszawa 1907, s. 6 i nast.; Ch. Lyon-Caen, L. Renault, Wykład prawa wekslowego i czekowego, z francuskiego przełożył i przypisami opatrzył A. Słomiński, Piotrków 1918, s. 392 i nast.; A. Żabicki, Prawo wekslowe i czekowe polskie i zagraniczne, Warszawa 1933, s. 224-227.

13 Zob. M. Scheffs, O wekslach i czekach według najnowszych ustaw polskich. Opracowanie dla użytku praktycznego, Poznań 1925, s. 88.

14 Zob. A. Żabicki, op. cit., s. 227.

15 Zob. R. Jastrzębski, Funkcje weksla w II Rzeczypospolitej, Warszawa 2003, s. 18 i nast.

16 Szerzej: M. Kuratów, Projekt jednostajnego prawa czekowego, Warszawa 1912. 
wencje genewskie, przede wszystkim pierwszą z nich. Zaistniały stan prawny powoduje, że do chwili obecnej ustawodawstwo czekowe zasadniczo dzieli się dychotomicznie na konwencyjne (genewskie) oraz niekonwencyjne ${ }^{17}$. W przypadku ostatniego ogromną rolę pełnią kraje anglosaskie, których regulacje czekowe odbiegają od unormowań przyjętych w Genewie. Warto zaznaczyć, że międzynarodowa unifikacja prawa czekowego była ściśle związana, z dokonanym w maju i czerwcu 1930 r. także w Genewie, międzynarodowym ujednoliceniem prawa wekslowego ${ }^{18}$. Czek stanowi bowiem szczególny rodzaj weksla, którego podstawową funkcją jest funkcja płatnicza, determinująca unormowania $\mathrm{z}$ zakresu prawa czekowego.

\section{Istota prawna czeku i jego funkcje}

Czek w praktyce stanowił i stanowi, w dużym uproszczeniu, polecenie skierowane do instytucji bankierskiej, w formie dokumentowej, wypłaty oznaczonej kwoty pieniężnej określonej osobie lub okazicielowi. Przyjmuje się, że dawny dokument czekowy miał po prostu formę weksla trasowanego (ciągnionego), wystawionego przez bank - depozytariusza kapitału pieniężnego ${ }^{19}$. Co do natury prawnej czeku należy odwołać się do opinii Stanisława Wróblewskiego, który stwierdził, że „natura zobowiązania czekowego jest zupełnie taka sama, jak zobowiązania $\mathrm{z}$ weksla; także warunki powstania zobowiązania są identyczne, [...] jest czek, tak samo jak weksel papierem wartościowym [...], jest odmianą przekazu, zarówno jak weksel"20. Zwrócił także na to uwagę w swojej rozprawie doktorskiej Adam Szpunar podkreślając, iż przekaz stanowi „podstawę do należytego zrozumienia weksla przekazowego i czeku i do rozwiązania wątpliwych kwestii, dotyczących wzajemnych stosunków wystawcy, trasata i remittenta"21. Wynika z tego, że czek stanowi sui generis rodzaj weksla trasowanego. Zresztą prawo angielskie określa czek jako weksel ciągniony (trasowany) na bankiera i płatny za okazaniem ${ }^{22}$.

Jednak w związku z wykorzystaniem podstawowej funkcji czeku - płatniczej, konieczne było odrębne uregulowanie tej instytucji. W przypadku bowiem we-

17 Zob. I. Heropolitańska, Prawo czekowe polskie i zagraniczne, Warszawa 1997.

18 Zob. J. Namitkiewicz, Konferencja Międzynarodowa Genewska (Maj-Czerwiec 1930 r.) w sprawie ujednostajnienia prawa wekslowego, Warszawa 1931.

19 Zob. S. Stecki, Czy czek ulega przyjęciu?, „Gazeta Sądowa Warszawska” 1928, nr 28.

20 S. Wróblewski, Polskie Prawo Czekowe z 14 listopada 1924 DZ. U. RZ. P. nast. 100 P. 927, Kraków 1926, s. 3-4; S. Wróblewski, Polskie prawo wekslowe i czekowe, Kraków 1930, s. 266.

21 A. Szpunar, Przekaz według kodeksu zobowiązań, Kraków 1937, s. 6.

22 Zob. A. D. Szczygielski, Zasady nowego polskiego prawa czekowego, „Gazeta Sądowa Warszawska” 1936, nr 29-30, s. 439. 
ksla podstawową funkcją była funkcja kredytowa ${ }^{23}$. Dlatego późniejsze regulacje prawne zawierały inne unormowania, niż w prawie wekslowym. Do istotnych różnic między czekiem a wekslem należy zaliczyć m.in., to że: czek jest płatny za okazaniem; nie ulega przyjęciu (akceptacji); trasatem mogą być tylko określone ustawowo podmioty; w pewnych okolicznościach czek może zostać odwołany; są inne terminy przedstawienia czeku do zapłaty; wystawienie czeku bez pokrycia wiąże się z sankcjami natury cywilnej i karnej ${ }^{24}$.

Czek, podobnie jak weksel, pełni cztery podstawowe funkcje: płatniczą, obiegową, gwarancyjną oraz kredytową ${ }^{25}$. Najważniejsze znaczenie ma pierwsza z wymienionych, czek bowiem stanowi przede wszystkim środek płatniczy. Oczywiście należy zaznaczyć, że wystawienie oraz wręczenie osobie uprawnionej czeku powoduje odroczenie terminu zapłaty, gdyż umorzenie długu następuje dopiero z chwilą uiszczenia kwoty pieniężnej, określonej w treści dokumentu czekowego, przez instytucję bankową - trasata ${ }^{26}$. W ten sposób czek stanowi surogat pieniądza. Co interesujące, należy stwierdzić, że banknot papierowy de facto jest czekiem na okaziciela, w którego treści trasatem i wystawcą jest ten sam podmiot - instytucja posiadająca przywilej emisyjny. Natomiast różnica polega na tym, iż banknot (pieniądz) ma charakter obligatoryjnego środka zapłaty ${ }^{27}$. W związku z tym, jak stwierdził Wacław Fabierkiewicz, stanowi „państwowy znak płatniczy, z reguły będący dobrem obiegowem, który posiada moc prawną zwalniania od zobowiązań" ${ }^{28}$.

Pozostałe dwie funkcje czeku - obiegowa i gwarancyjna, umożliwiają wykorzystanie czeku, jako środka płatniczego. Pierwsza zapewnia cyrkulację dokumentów czekowych, a faktycznie przenoszenie praw inkorporowanych w treści tego papieru wartościowego, w szczególności dotyczy to czeków na okaziciela. Natomiast druga zabezpiecza obrót czekowy. Składają się na nią, poza abstrakcyjnym charakterem zobowiązania, formalizmem oraz charakterem odpowiedzialności czekowej, również szczególne instytucje prawa czekowego, takie jak m.in. odpowiedzialność za wystawienie czeku bez pokrycia, szczególne rodzaje czeków, np. rozrachunkowy, certyfikowany, zakreślony. Ostatnia funkcja - kredytowa, powinna $\mathrm{w}$ zasadzie mieć charakter drugorzędny. Jednak w praktyce II Rzeczypospolitej była często wykorzystywana, w związku z sankcjami cywil-

23 Szerzej: M. Michalski, Funkcje gospodarcze weksla, „Przegląd Ustawodawstwa Gospodarczego” 1992, nr 4; R. Jastrzębski, Wykorzystanie funkcji kredytowej weksla, „Przegląd Ustawodawstwa Gospodarczego" 1998, nr 3.

24 S. Janczewski, op. cit., s. 498-499; A. Szpunar, Komentarz do prawa wekslowego..., s. 256-257.

25 Zob. M. Michalski, Funkcje gospodarcze czeku w świetle polskiego ustawodawstwa czekowego, „Przegląd Prawa Handlowego" 1993, nr 12, 13.

26 Zob. A. Szpunar, O zapłacie dokonanej za pomoca czeku, „Przegląd Sądowy” 1993, nr 3.

27 Zob. A. Peretz, Polskie prawo czekowe, „Przegląd Prawa Handlowego” 1925, s. 285.

28 W. Fabierkiewicz, Nauka o pieniądzu, Warszawa 1932, s. 9. 
nymi, a przede wszystkim karnymi za wystawienie tzw. czeku blankowego (bez pokrycia). Dotyczyła dwóch rodzajów czeku - czeku in blanco i postdatowanego ${ }^{29}$. Co interesujące, tego rodzaju czeki określano mianem ,weksli z żyrem prokuratora".

\section{Polskie prawo czekowe}

\section{Okres po odzyskaniu niepodległości}

Prawo czekowe obowiązujące in statu nascendi państwowości polskiej stanowiło spuściznę systemów prawnych państw zaborczych. W związku z tym na poszczególnych obszarach dawnych dzielnic zaborczych obowiązywały różne regulacje czekowe. Konkretnie zaś:

1) na obszarze dawnego zaboru austriackiego - ustawa czekowa z 3 kwietnia $1906 \mathrm{r}$.

2) na obszarze byłego zaboru niemieckiego - ustawa czekowa z 11 marca $1908 \mathrm{r}$.

3) na Spiszu i Orawie - ustawa czekowa węgierska z 31 grudnia 1908 r. ${ }^{30}$

W ostatnim wypadku ustawa węgierska została zastąpiona, na podstawie $\$ 2$ pkt 2 litera e rozporządzenia Rady Ministrów z dnia 14 listopada $1922 \mathrm{r}$. $\mathrm{w}$ przedmiocie organizacji sądownictwa na Spiszu i Orawie i rozciągnięcia na ten obszar mocy obowiązującej niektórych ustaw i rozporządzeń ${ }^{31}$, prawem czekowym austriackim z 1906 r. W taki sposób nastąpiła unifikacja prawa czekowego na części ówczesnego państwa polskiego, które stanowiło dawny obszar Austro-Węgier.

W przypadku byłego zaboru rosyjskiego, zarówno Królestwa Polskiego, jak i pozostałych ziem wchodzących w skład tego zaboru, brak było jakichkolwiek unormowań. W praktyce, zaś czek był wykorzystywany, a zasady jakimi rządził się obrót czekowy miały charakter zwyczajowy. Związane z obrotem czekowym zwyczaje handlowe, jak stwierdził Jan Namitkiewicz, były „dalekie od jednostaj-

29 Zob. A. D. Szczygielski, Czek postdatowany, „Gazeta Sądowa Warszawska” 1937, nr 12, 13, 14, 15, 16, 17, 18; R. Jastrzębski, Funkcja kredytowa czeku, „Przegląd Ustawodawstwa Gospodarczego” 2003, nr 8.

30 Szerzej: S. Wróblewski, Ustawa z dnia 3 kwietnia 1906 L. 84, D. U. P. o czeku, Kraków 1907; M. Kuratow, Ustawa czekowa niemiecka $z$ dnia 11 Marca 1908 roku, „Gazeta Sądowa Warszawska” 1908 , nr 16; Ustawa Handlowa wraz z ustawami dodatkowemi w tłómaczeniu Prof. Dra Józefa Rosenblata. Wydanie trzecie z objaśnieniami Prof. Dr. Stanisława Wróblewskiego. Tom II Ustawy Dodatkowe, Kraków 1917, s. 664 i nast.

31 Dz. U. Nr 90, poz. 833. Rozporządzenie zostało wydane na podstawie art. 2 ustawy z dnia 26 października 1921 r. w przedmiocie przepisów prawnych, obowiązujących na obszarze Spisza i Orawy, należącym do Rzeczypospolitej Polskiej (Dz. U. Nr 89, poz. 657). 
ności”32. Dlatego obrót czekowy związany był z unormowaniami wydawanymi przez poszczególne instytucje bankowe. Egzemplifikacją takiej prawotwórczej działalności były regulacje wydane przez Pocztową Kasę Oszczędności ${ }^{33}$. Również obroty czekowe dotyczyły stosunków międzypaństwowych. Jeżeli chodzi o II Rzeczpospolitą było to związane z zawarciem przez Polskę i Niemcy tzw. konwencji górnośląskiej (genewskiej) w 1922 r. ${ }^{34}$, która była związana z podziałem Górnego Śląska. W związku z tym konieczna stała się tymczasowa regulacja obrotu czekowego na tym obszarze. Konsekwencją tego był podpisany w dniu 15 maja 1922 r. układ między Polską a Niemcami w przedmiocie pocztowego obrotu czekowego ${ }^{35}$.

Warto zaznaczyć, że pierwsze próby kodyfikacji prawa czekowego związane były z nadużyciami fiskalnymi, gdyż wystawianie czeków co do zasady nie podlegało obowiązkowi uiszczenia opłaty stemplowej (skarbowej) ${ }^{36}$. W ten sposób uczestnicy obrotu prawnego zamiast wystawiać weksle, od których pobierana była taka opłata, zaczęli wykorzystywać instytucję czeku - jego funkcję kredytową. Dlatego ówczesne ministerstwo skarbu zajęło się kodyfikacją prawa czekowego w 1921 r., w tym celu wysłało do zaopiniowania projekt tymczasowej ustawy czekowej. Projekt ten został uznany przez Maurycego Allerhanda za „,pracę poronioną”, bowiem przy jego „opracowaniu nie uwzględniono ani bogatej literatury prawa czekowego, ani też protokółów konferencji peszteńskiej, odbytej w roku 1907 i protokołów konferencji haskiej z roku 1912 zawierających nader cenny materjał dla kodyfikatora" ${ }^{37}$. Co istotne, recenzent projektu zaproponował pozostawienie status quo, przy czym na obszar dawnego zaboru rosyjskiego miała zostać rozciągnięta jedna $\mathrm{z}$ obowiązujących ustaw czekowych - austriacka albo niemiecka. Dokonana w taki sposób unifikacja prawa czeko-

32 J. Namitkiewicz, Obecny stan prawodawstwa handlowego w b. Królestwie Kongresowem, „Ruch Prawniczy i Ekonomiczny" 1921, s. 438.

33 Zob. Postanowienia o obrocie czekowym Pocztowej Kasy Oszczędności, Warszawa 1919.

34 Zob. Ustawa z dnia 24 maja 1922 r. w przedmiocie ratyfikacji konwencji niemiecko-polskiej, dotyczącej Górnego Śląska, podpisanej w Genewie dnia 15 maja 1922 r. (Dz. U. Nr 44, poz. 370); konwencja niemiecko-polska dotycząca Górnego Śląska, podpisana w Genewie dnia 15 maja 1922 roku (Dz. U. Nr 44, poz. 371). Szerzej: A. Szczepański, Górny Ślask w świetle wykonania konwencji genewskiej, Warszawa 1929.

Zob. ustawa z dnia 24 maja 1922 r. o ratyfikacji układu między Polską a Niemcami w przedmiocie pocztowego obrotu czekowego, podpisanego w Genewie dnia 15 maja 1922 r. (Dz. U. Nr 51, poz. 453); Układ między Polską a Niemcami w przedmiocie pocztowego obrotu czekowego (Dz. U. Nr 51, poz. 454); Protokół wymiany dokumentów ratyfikacyjnych Układu Polsko-Niemieckiego w przedmiocie pocztowego obrotu czekowego, podpisanego w Genewie, dn. 15 maja 1922 roku (Dz. U. Nr 51, poz. 455). Zob. prace w Sejmie Ustawodawczym: sprawozdanie stenograficzne z 312 posiedzenia Sejmu Ustawodawczego z dnia 23 maja 1922 r., łam 70; druk sejmowy Nr 3578 i załącznik do tego druku, zawierający ustawę.

36 Zob. A. Górski, Prawo wekslowe i czekowe, Warszawa 1925, s. 305.

37 M. Allerhand, Uwagi do projektu tymczasowej ustawy czekowej, „Przegląd Prawa i Administracji” 1922, z. 1-3, s. 18. 
wego na obszarze państwa polskiego miała zaspokoić bieżące potrzeby obrotu czekowego. Natomiast, po szczegółowej analizie projektu tymczasowej ustawy czekowej, Maurycy Allerhand uznał, że jego wprowadzenie w życie stanowi reformatio in peius.

Projekt ustawy czekowej, na podstawie uchwały Rady Ministrów z dnia 16 stycznia 1922 r., został przesłany do Sejmu przez Ministra Skarbu i Ministra Sprawiedliwości. Składał się z dwóch załączników - pierwszy zawierał projekt ustawy czekowej (49 artykułów), drugi zaś jego uzasadnienie ${ }^{38}$. Projekt został odesłany do Komisji Skarbowo-Budżetowej ${ }^{39}$. W uzasadnieniu projektu podkreślano, że czek miał służyć przede wszystkim „obrotowi wewnętrznemu i powinien jak najprędzej wejść w szerokie zastosowanie” ${ }^{30}$. Ówcześnie bowiem, mimo obowiązywania w dawnym zaborze pruskim i austriackim ustaw, obrót czekowy był stosunkowo niewielki. Natomiast „największa część Polski nie posiada zupełnie odrębnego prawa czekowego”, chociaż „,rozwinął się tam wprawdzie wcale żywy obrót czekowy drogą praktyki bankowej, ale odczuwa on dotkliwie brak podstawy prawnej, który nie pozwala mu pozbyć się charakteru lokalnego i nie pozwala czekom pełnić na szeroką skalę funkcji środka płatniczego" ${ }^{41}$. Dlatego konieczne dla twórców projektu było jak najszybsze uchwalenie prawa czekowego, zresztą nie tylko dla obszaru dawnej dzielnicy rosyjskiej, lecz regulacji ogólnopaństwowej. Miała ona mieć charakter tymczasowy, ostateczne zaś unormowanie polskiego prawa czekowego miało być dokonane przez ówczesną Komisję Kodyfikacyjną, po zakończeniu przez nią prac nad projektem prawa wekslowego. W dalszej części uzasadnienia stwierdzono, iż „tymczasowy charakter ustawy czekowej pozwoli tym przepisom przejść próbę praktyki, a wypróbowanie ich odda usługę także kodyfikacji polskiego prawa wekslowego" ${ }^{\prime 2}$.

Następnie Komisja Skarbowo-Budżetowa podjęła jednomyślną uchwałę, powziętą na posiedzeniu w dniu 9 marca 1922 r., dotyczącą uchwalenia przez Sejm ustawy czekowej ${ }^{43}$. Komisja dokonała w zasadzie niewielkich zmian w projekcie ustawy. Najważniejszą z nich była rezygnacja z opłaty stemplowej oraz związanych z tym dalszych unormowań, w stosunku do czeków płatnych w Polsce oraz za granicą, które odpowiadały projektowi ustawy. Kolejny etap prac sejmowych nad projektem ustawy czekowej przypadł na grudzień 1922 r. Wtedy Prezydent Ministrów (premier) - Julian Nowak, na podstawie uchwały Rady Ministrów z dnia 9 grudnia 1922 r., przesłał do Sejmu I kadencji projekt ustawy czeko-

38 Druk sejmowy Nr 3281.

39 Sprawozdanie stenograficzne z 288 posiedzenia Sejmu Ustawodawczego z dnia 24 lutego 1922 r., łam 6.

40 Załącznik 2 do druku sejmowego Nr 3281, s. 11.

41 Ibidem, s. 11-12.

42 Ibidem, s. 15.

43 Druk sejmowy Nr 3390 oraz załącznik - ustawa czekowa (48 artykułów). 
wej wraz z uzasadnieniem ${ }^{44}$. Stanowiły one de facto powtórzenie wniesionego do Sejmu Ustawodawczego, wcześniej, bo w styczniu tegoż roku, tymczasowego projektu ustawy czekowej. Projekt został w styczniu 1923 r. odesłany do Komisji Skarbowej ${ }^{45}$. W ten sposób projekt ustawy czekowej był przedmiotem prac sejmowych, które jednak nie dały żadnego rezultatu w postaci uchwalenia ustawy czekowej.

\section{Rozporządzenie Prezydenta Rzeczypospolitej o prawie czekowym}

Prace nad kodyfikacją prawa czekowego nabrały przyspieszenia w związku z przygotowywaną reformą gospodarczą. Jednocześnie bowiem z pracami związanymi z prawem wekslowym Komisja Kodyfikacyjna zajęła się przygotowaniem projektu prawa czekowego. Prace zostały rozpoczęte w 1923 r., twórcami zaś wstępnego projektu byli: wiceprezes sekcji prawa handlowego Stanisław Wróblewski - referent oraz Marek Kuratowski - koreferent ${ }^{46}$. Następnie projekt został rozesłany członkom sekcji, którzy zostali zobowiązani do zgłoszenia uwag na początku przyszłego roku. Ostatecznie w dniach 3-4 czerwca 1924 r. Komitet Organizacyjny Prac Komisji Kodyfikacyjnej przyjął projekt prawa czekowego ${ }^{47}$, który wraz z motywami ukazał się na łamach „Gazety Sądowej Warszawskiej”48.

Warto podkreślić, że opracowanie projektu odbyło się prawie równocześnie z kodyfikacją prawa wekslowego, o czym świadczą sprawozdania z prac Komisji Kodyfikacyjnej ${ }^{49}$. Wynikało to oczywiście z faktu, iż czek stanowił i stanowi po prostu rodzaj weksla trasowanego płatnego za okazaniem, którego trasatem jest wyłącznie instytucja bankowa. Problemem w opracowaniu projektu prawa czekowego był faktyczny brak, w porównaniu z prawem wekslowym - Konferencja

44 Druk sejmowy Nr 23 (dwa załączniki: 1 - projekt ustawy czekowej oraz 2 - uzasadnienie).

45 Sprawozdanie stenograficzne z 6 posiedzenia Sejmu Rzeczypospolitej z dnia 16 stycznia 1923 r., łam 14-15.

46 Komisja Kodyfikacyjna Rzeczypospolitej Polskiej, Dział Ogólny, t. I, z. 6, Warszawa 1924, s. 166; zob. Projekt ustawy czekowej z motywami przez St. Wróblewskiego, ,Czasopismo Prawnicze i Ekonomiczne” 1923, nr 1-6; S. Grodziski twierdzi, że projekt ustawy czekowej z 1924 r. opracowali: A. Doliński, A. Górski, M. Kuratow-Kuratowski, zaś prawa czekowego z 1936 r. J. Sułkowski [S. Grodziski, Prace nad kodyfikacją i unifikacja polskiego prawa prywatnego (1919-1947), „Kwartalnik Prawa Prywatnego" 1992, z. 1-4, s. 15]; L. Górycki, Historia, koncepcja i systematyka projektu ustawy czekowej z 1923 r., [w:] Świat, Europa, Mała Ojczyzna. Studia ofiarowane profesorowi Stanisławowi Grodziskiemu w 80-lecie urodzin, red. M. Małecki, Bielsko-Biała 2009.

47 Komisja Kodyfikacyjna Rzeczypospolitej Polskiej, Dział Ogólny, t. I, z. 7, Warszawa 1925, s. 193.

48 Z Komisji Kodyfikacyjnej R.P. Projekt Ustawy Czekowej uchwalony przez Sekcje Handlowa Komisji Kodyfikacyjnej, „Gazeta Sądowa Warszawska” 1924, nr 13, s. 185-187; nr 14, 200-205.

49 Zob. Komisja Kodyfikacyjna Rzeczypospolitej Polskiej, Dział Ogólny, t. I, z. 7, Warszawa 1925, s. 183; Komisja Kodyfikacyjna Rzeczypospolitej Polskiej, Dział Ogólny, t. I, z. 8, Warszawa 1926, s. 211; Komisja Kodyfikacyjna Rzeczypospolitej Polskiej, Dział Ogólny, t. I, z. 11, Warszawa 1929, s. 354; Komisja Kodyfikacyjna Rzeczypospolitej Polskiej, Dział Ogólny, t. I, z. 12, Warszawa 1929, s. 381 . 
Haska z 1912 r., regulacji w postaci międzynarodowej umowy, a konkretnie regulaminu wekslowego - ustawy jednostajnej o wekslu ciągnionym i prostym ${ }^{50}$. Dlatego Komisja Kodyfikacyjna, korzystając jedynie z przyjętych w Hadze rezolucji dotyczących prawa czekowego, musiała wypracować wiele własnych rozwiązań. Projekt ustawy czekowej, uchwalony przez Sekcję Prawa Handlowego Komisji Kodyfikacyjnej, miał charakter jednolity, tzn. stanowił jedną całość pozbawioną odesłań do prawa wekslowego. Na łamach „Gazety Sądowej Warszawskiej” odbyła się dyskusja nad projektem, której uczestnikami byli Franciszek Nowodworski - I Prezes Sądu Najwyższego, oraz A. Bardzkii ${ }^{51}$ Krytykowali oni m.in. wadliwy układ oraz stronę językową projektu. Pierwszy z nich zaproponował nawet własny projekt ustawy czekowej, który został dołączony do zamieszczonego artykułu.

Ostatecznie w dniu 1 stycznia 1925 r. weszło w życie rozporządzenie Prezydenta Rzeczypospolitej z dnia 14 listopada 1924 r. o prawie czekowem ${ }^{52}$. Rozporządzenie zostało wydane, na podstawie art. 1 litera E pkt 5 i art. 2 ustawy z dnia 31 lipca 1924 r. o naprawie Skarbu Państwa i poprawie gospodarstwa społecznego ${ }^{53}$ oraz zgodnie z uchwałą Rady Ministrów z dnia 15 października 1924 r. Nowe prawo czekowe uchyliło obowiązujące na obszarze II Rzeczypospolitej regulacje, oprócz dotyczących opłat państwowych oraz samorządowych. Z dniem wejścia $\mathrm{w}$ życie rozporządzenia została dokonana równocześnie kodyfikacja i unifikacja prawa czekowego na ówczesnym obszarze państwa polskiego. Prawo czekowe z 1924 r. dzieliło się na XIV tytułów, podzielonych na 61 artykułów ${ }^{54}$. Podstawę stanowily rezolucje haskie z 1912 r. oraz rozporządzenie Prezydenta Rzeczypospolitej z dnia 14 listopada 1924 r. o prawie wekslowem ${ }^{55}$. W ostatnim wypadku chodziło o instytucje prawne w ten sam sposób unormowane jak $\mathrm{w}$ prawie wekslowym, m.in. indos, legitymacja formalna, przedawnienie, poszukiwanie zwrotne, roszczenia z tytułu niesłusznego (bezpodstawnego) wzbogacenia. Poza tym wpływ na polskie rozporządzenie czekowe miały ustawy państw zaborczych - niemiecka oraz austriacka ${ }^{56}$.

50 Zob. J. Namitkiewicz, Ustawa wekslowa jednostajna przyjęta przez międzynarodowa Konwencję Haską z 23 lipca 1912 r. Przekład tekstu urzędowego, Warszawa 1919.

51 Zob. F. Nowodworski, Z powodu projektu ustawy czekowej, „Gazeta Sądowa Warszawska” 1924, nr 20; A. Bardzki, Jeszcze słów kilka o projekcie ustawy czekowej, „Gazeta Sądowa Warszawska” 1924 nr 38 .

52 Dz. U. Nr 100, poz. 927.

53 Dz. U. Nr 71, poz. 687.

54 Tytuły: I. Forma; II. Indos; III. Przedstawienie do zapłaty; IV. Zapłata; V. Odpowiedzialność; VI. Zwrotne poszukiwanie; VII. Wtóropisy; VIII. Czeki zaginione; IX. Przedawnienie; X. Roszczenie z tytułu niesłusznego zbogacenia się; XI. Skutki braku pokrycia; XII. Zbieg ustaw; XIII. Przepisy procesowe; XIV. Przepisy przejściowe.

55 Dz. U. Nr 100, poz. 926.

56 J. Namitkiewicz, Podręcznik Prawa Handlowego, wekslowego, czekowego..., s. 462. 
Wejście w życie prawa czekowego wywołało sporo krytyki ze strony ówczesnego świata prawniczego oraz gospodarczego. Niektórzy, jak stwierdził Adolf Peretz, uważali, że należy dokonać przekładu rozporządzenia na język polski ${ }^{57}$. Regulacja nie zawierała szczególnych rodzajów czeku, tzn. zakrzyżowanego oraz certyfikowanego, które były w obrocie m.in. w Wielkiej Brytanii i Stanach Zjednoczonych Ameryki Północnej. Jednak unormowanie nowych rodzajów czeku, jak wynika z uzasadnienia do projektu Komisji Kodyfikacyjnej, miało być przedwczesne, czy wręcz ryzykowne, zwłaszcza w odniesieniu do tzw. czeków certyfikowanych. Dlatego odnoszące się do nich regulacje pozostawiono praktyce obrotu czekowego ${ }^{58}$. Na podstawie delegacji zawartych w rozporządzeniu czekowym zostały wydane regulacje prawne, które dotyczyły izb rozrachunkowych, protestu, dni świątecznych ${ }^{59}$, a także została wydana ustawa z dnia 22 kwietnia 1926 r. określająca właściwość sądów w sprawach o przestępstwo, przewidziane w art. 51 rozporządzenia Prezydenta Rzeczypospolitej z dnia 14 listopada 1924 r. o prawie czekowem ${ }^{60}$.

Na zakończenie należy podkreślić, że wydanie rozporządzenia czekowego, zgodnie z delegacją zawartą w ustawie o naprawie Skarbu Państwa i poprawie gospodarstwa społecznego, miało na celu wzmożenie i ułatwienie obrotu pieniężnego, a in concreto obrotu bezgotówkowego i obiegu tytułów na okaziciela. Zwracano poza tym uwagę na to, iż czek jest czynnikiem antyinflacyjnym, a Jan

57 A. Peretz, op. cit., s. 293-294. Szerzej: S. Paneth, Kilka uwag o nowem polskiem prawie czekowem, „Głos Prawa” 1925, nr 1-2; J. Trammer, Nowe prawo czekowe, „Palestra” 1925, nr 1.

58 Z Komisji Kodyfikacyjnej R.P. Projekt Ustawy Czekowej uchwalony przez Sekcję Handlowa Komisji Kodyfikacyjnej, „Gazeta Sądowa Warszawska” 1924, nr 14, s. 203; zob. J. Namitkiewicz, Polska ustawa czekowa a bezpieczeństwo obrotu, „Przegląd Prawa Handlowego”, 1925, s. 29-32.

59 Delegacje były zawarte w: art. 16 ust. 2, art. 32 ust. 2, art. 60 rozporządzenia o prawie czekowem z $1924 \mathrm{r}$.

Sprawy te regulowały:

1) w przypadku izb rozrachunkowych, przez cały okres kiedy obowiązywało prawo czekowe z 1924 r., nie zostało wydane rozporządzenie Ministra Skarbu w porozumieniu z Ministrem Sprawiedliwości, regulujące ich działalność, natomiast w praktyce uznawano za nie izby działające przy oddziałach Banku Polskiego (szerzej: E. Dąbrowski, Izby rozrachunkowe, Warszawa 1926, s. 36 i nast.; Dr. Ruvido, Bank Polski. Organizacja. Statut. Ogólne zasady załatwiania czynności, Warszawa 1927, s. 8);

2) rozporządzenie Ministra Sprawiedliwości w porozumieniu z Ministrem Przemysłu i Handlu z dnia 16 czerwca 1925 r. o oznaczeniu organów sądowych upoważnionych do sporządzania protestów wekslowych i czekowych (Dz. U. Nr 61, poz. 431), rozporządzenie Ministra Sprawiedliwości w porozumieniu z Ministrem Przemysłu i Handlu z dnia 22 grudnia 1932 r. o uchyleniu upoważnienia organów sądowych do sporządzania protestów wekslowych i czekowych (Dz. U. Nr 119, poz. 977); szerzej o proteście: R. Jastrzębski, Protest wekslowy w prawie polskim. Geneza. Historia. Znaczenie współczesne, „Studia Prawa Prywatnego” 2006, z. 3;

3) rozporządzenie Prezydenta Rzeczypospolitej z dnia 15 listopada 1924 r. o dniach świątecznych (Dz. U. Nr 101, poz. 928), ustawa z dnia 18 marca 1925 r. w przedmiocie zmiany rozporządzenia Prezydenta Rzeczypospolitej z dnia 15 listopada 1924 r. o dniach świątecznych (Dz. U. R. P. Nr 101, poz. 928, Dz. U. Nr 34, poz. 234).

60 Dz. U. Nr 44, poz. 268. 
Namitkiewicz stwierdził expressis verbis, że ,gdyby czek w naszym kraju był się tak zaaklimatyzował zwyczajowo, jak w Anglji, nie przechodzilibyśmy choroby inflacji i deprecjacji naszego pieniądza i ciężkich chwil z niemi związanych!”61.

\section{Ustawa prawo czekowe z $1936 \mathrm{r}$.}

Kolejna kodyfikacja prawa czekowego była związana $\mathrm{z}$ międzynarodową unifikacją tego działu prawa. Należy zaznaczyć, że bezpośrednio dotyczyła prac nad międzynarodowym ujednostajnieniem prawa wekslowego. W latach 20. Liga Narodów podjęła inicjatywę, której celem było opracowanie projektu prawa czekowego. Szczególną aktywność w tej mierze przejawiał Komitet Ekonomiczny Ligi Narodów, a także Międzynarodowa Izba Handlowa ${ }^{62}$. Na zakończonej w czerwcu 1930 r. w Genewie konferencji, w sprawie ujednolicenia prawa wekslowego, został opracowany kwestionariusz, dotyczący jednolitej ustawy czekowej. Przekazano go delegacjom państw w celu uzyskania opinii. Te ostatnie miały być podstawą obrad przyszłej konferencji ${ }^{63}$. W dniach 23 lutego - 19 marca 1931 r. w Genewie odbyła się następna konferencja, której z kolei celem była międzynarodowa unifikacja prawa czekowego; nota bene stronę polską reprezentowali Jan Namitkiewicz i Józef Sułkowski. Ostatecznie w dniu 19 marca tegoż roku zostały na niej uchwalone trzy konwencje:

1) w sprawie jednolitej ustawy o czekach;

2) o uregulowaniu pewnych kolizji ustaw w przedmiocie czeków;

3) dotycząca opłaty stemplowej w przedmiocie czeków ${ }^{64}$.

Podstawowe znaczenie dla krajowego prawa czekowego miała pierwsza z konwencji, a konkretnie dwa do niej załączniki - pierwszy zawierający tekst jednolitej ustawy czekowej, drugi zaś składający się z tzw. rezerwatów, czyli możliwych odstępstw od jednolitego tekstu. Państwo polskie w dniu 18 marca 1937 r. złożyło oświadczenia o przystąpieniu do wymienionych konwencji ${ }^{65}$. Uczestnictwo strony polskiej w konferencji genewskiej i podpisanie przez polską delegację wszystkich konwencji spowodowało, iż konieczne stało się dostosowanie czekowego prawa krajowego. Zagadnieniem tym zajęła się Komisja Kodyfikacyjna.

61 J. Namitkiewicz, Polska ustawa czekowa a bezpieczeństwo..., s. 26.

62 Szerzej: J. Sułkowski, $W$ sprawie unifikacji prawa wekslowego i czekowego, „Ruch Prawniczy i Ekonomiczny" 1930; A. Glasner, A. Thaler, Prawo wekslowe i czekowe. Komentarz, Część II: Prawo czekowe, Kraków 1938, s. V-VI; A. D. Szczygielski, Zasady nowego polskiego prawa czekowego..., s. 438. A. Żabicki podaje, że prace zostały już podjęte w 1925 r. na Konferencji Brukselskiej (A. Żabicki, op. cit., s. 228).

63 Zob. Dr. Wł. Ch., O jednolite prawo czekowe, „Gazeta Bankowa” 1931, nr 7.

64 Dz. U. z 1937 r. Nr 26, poz. 181, 183, 185. Zbiór Traktatów Rzeczypospolitej Polskiej. 1937. II, Warszawa 1937. Szerzej: Conférence internationale pour l'Unification du Droit en matiére de Lettres de change, Billets à ordre et Chéques (Deuxième session), Genewa 1931.

65 Dz. U. z 1937 r. Nr 26, poz. 182, 184, 186. 
Podkomisja prawa handlowego uchwaliła projekt nowego prawa czekowego, co nastąpiło w dwóch czytaniach - w pierwszym 28-31 lipca oraz w drugim 11 sierpnia 1933 r. Następnie projekt został przyjęty w dniu 6 września 1933 r. przez Kolegium Uchwalające Komisji Kodyfikacyjnej, a w dniu 13 września przekazany Ministrowi Sprawiedliwości ${ }^{66}$. Projekt został poddany zmianom, które miały na celu dostosować go do wydanych w tym czasie nowych regulacji prawnych, takich jak: kodeks zobowiązań, kodeks handlowy, prawo upadłościowe, prawo układowe ${ }^{67}$, w tym podlegał uzgodnieniom międzyministerialnym. Po tych wszystkich zmianach oraz konsultacjach został przekazany Radzie Ministrów, która uchwaliła w dniu 7 lutego $1936 \mathrm{r}$. rządowy projekt ustawy prawo czekowe. Został on przesłany pismem Ministra Sprawiedliwości z dnia 8 lutego $1936 \mathrm{r}^{68}$ do polskiego parlamentu.

Prace dotyczące projektu prawa czekowego były prowadzone przez Komisję Prawniczą Sejmu, a konkretnie przez osobną podkomisję, powołaną w dniu 4 marca, której przewodniczył Bohdan Podoski. Projekt został rozpatrzony przy współudziale powołanych rzeczoznawców w osobach: Adama Chełmońskiego, Wacława Fajansa, Stanisława Schultza ${ }^{69}$. Posłem sprawozdawcą był Zygmunt Sioda, na którego wniosek Sejm uchwalił projekt ustawy prawo czekowe ${ }^{70}$. Przyjęty przez Sejm projekt, ze zmianami wprowadzonymi przez podkomisję, został przekazany Senatowi, a ostatecznie Komisji Prawniczej Senatu, której przewodniczył Stanisław Wróblewski. Komisja wprowadziła niewielkie poprawki do projektu, który został uchwalony przez Senat, a następnie przez Sejm w dniu 28 marca 1936 r. $^{71}$ Ustawa została w dniu 28 kwietnia 1936 r. podpisana przez Prezydenta Rzeczypospolitej - Ignacego Mościckiego, i ogłoszona w Dzienniku Ustaw w dniu 11 maja 1936 r. ${ }^{72}$ Zgodnie $\mathrm{z}$ art. 88 weszła w życie $\mathrm{z}$ dniem 1 lipca 1936 r. i obowiązuje do dnia dzisiejszego.

66 Komisja Kodyfikacyjna, Dział Ogólny, z. 16, Warszawa 1934, s. 8.

67 Chodzi o: rozporządzenie Prezydenta Rzeczypospolitej z dnia 27 października 1933 r. Kodeks zobowiązań (Dz. U. Nr 82, poz. 598); rozporządzenie Prezydenta Rzeczypospolitej z dnia 27 czerwca 1934 r. Kodeks handlowy (Dz. U. Nr 57, poz. 502); rozporządzenie Prezydenta Rzeczypospolitej z dnia 24 października 1934 r. Prawo upadłościowe (Dz. U. Nr 93, poz. 834); rozporządzenie Prezydenta Rzeczypospolitej z dnia 24 października 1934 r. Prawo o postępowaniu układowem (Dz. U. Nr 93, poz. 836).

68 Pismo Ministra Sprawiedliwości Nr. I. C. 1720/1/9/36; zob. Druk sejmowy Nr 62; A. D. Szczygielski, Nowelizacja prawa wekslowego i czekowego, Warszawa 1939, s. 24.

69 Zob. Sprawozdanie Komisji Prawniczej o rządowym projekcie ustawy Prawo czekowe /druk sejmowy Nr 62/, Druk sejmowy Nr 107.

70 Zob. sprawozdanie stenograficzne z 21 posiedzenia Sejmu w dniu 17 marca 1936 r., łam 33-40.

71 Zob. sprawozdanie Komisji Prawniczej o zmianach wprowadzonych przez Senat do uchwalonego przez Sejm w dniu 17 marca 1936 r. projektu ustawy Prawo czekowe /druki sejmowe nr 62 i 107/, Druk sejmowy Nr 162; sprawozdanie stenograficzne z 25 posiedzenia Sejmu w dniu 28 marca 1936 r., łam 6-7.

72 Dz. U. Nr 37, poz. 283; zob. Przegląd Prac Ustawodawczych z czerwcowej Sesji Nadzwyczajnej 1936 R. oraz Sesji Zwyczajnej 1936/1937 R., Warszawa 1937, s. 36. 
Ustawa składa się z XVI działów ${ }^{73}$, które podzielone są na 88 artykułów. W porównaniu z rozporządzeniem czekowym z $1924 \mathrm{r}$. ustawa z $1936 \mathrm{r}$. jest prima facie regulacją bardziej obszerną. Analizując prawo czekowe z 1936 r. należy na wstępie zaznaczyć, że stanowi wypadkową dwóch załączników - jednolitej ustawy czekowej i tzw. rezerwatów, do pierwszej Konwencji Genewskiej z 1931 r. w sprawie jednolitej ustawy o czekach. W związku z tym polskie prawo czekowe z 1936 r. zostało po prostu oparte na międzynarodowej unifikacji tego działu prawa prywatnego. Dlatego też wyraźnie różni się od rozporządzenia z 1924 r. Zmiany w prawie czekowym można podzielić dychotomicznie na: zmierzające do uzgodnienia prawa czekowego z prawem wekslowym oraz właściwe wyłącznie temu pierwszemu. Natomiast najważniejsze zmiany dotyczą: ustawowej regulacji czeku in blanco; czeku postdatowanego; czeków zakrzyżowanych; lepszej regulacji czeku rozrachunkowego oraz odpowiedzialności związanej z wystawieniem czeku bez pokrycia ${ }^{74}$. Poza tym prawo czekowe zawiera delegacje do wydania rozporządzeń wykonawczych, które dotyczą niszczenia odpisów protestów czekowych oraz izb rozrachunkowych ${ }^{75}$.

Nawet tak krótka charakterystyka prawa czekowego z 1936 r. pozwala stwierdzić, że nowa regulacja stanowiła istotną zmianę w obowiązującym prawie cze-

73 Działy: I. Wystawienie i forma czeku; II. Przeniesienie; III. Poręczenie czekowe; IV. Przedstawienie i zapłata; V. Czek zakreślony i czek rozrachunkowy; VI. Zwrotne poszukiwanie z powodu niezapłacenia; VII. Wtóropisy; VIII. Zmiany; IX. Przedawnienie; X. Przepisy ogólne; XI. Roszczenie z tytułu niesłusznego zbogacenia; XII. Skutki braku pokrycia; XIII. Kolizja ustaw; XIV. Protest; XV. Czeki zaginione; XVI. Przepisy końcowe i przejściowe.

74 Szerzej: A. D. Szczygielski, Czekowe prawo, [w:] Encyklopedja Podręczna Prawa Prywatnego, założona przez H. Konica, red. F. Zoll i J. Wasilkowski, suplement do tomów I i II, Warszawa 1931-1939, s. XCVI-CXVII; idem, Nowelizacja prawa czekowego, „Głos Sądownictwa” 1936; idem, Zasady nowego polskiego prawa czekowego..., nr 29-30, 31-32, 33-34, 37-38, 40, 41, 42, 43, 44, 45-46, 47; idem, Nowelizacja prawa wekslowego..., s. 24-32; idem, Czek w znaczeniu ustawowym, ,Głos Prawa” 1938, nr 6-8; S. Kowalski, Prawo Wekslowe (Ustawa z 28 kwietnia 1936 r. Dz. U. R. P. Nr. 37, poz. 282). Prawo Czekowe (Ustawa $z$ dnia 28 kwietnia 1936 r. Dz. U. R. P. Nr. 37, poz. 283). Orzecznictwo Sąu Najwyższego. Przepisy o protestach. Przepisy pocztowe. Ustawy związkowe i dodatkowe. Objaśnienia, Lwów 1936, s. 111-114; J. Namitkiewicz, Nowe Prawo Czekowe (Omówienie najważniejszych zmian w stanie prawnym z przed 1.VII.1936.), „Przegląd Notarialny” 1936, nr 17-18; H. Fisch, Zarys nowego prawa czekowego, „Gazeta Bankowa” 1936, nr 11-12; H. F., Reforma prawa wekslowego i czekowego, „Gazeta Bankowa” 1936, nr 7-8; A. Macholz, Nowe prawo wekslowe i czekowe. Szkic porównawczy, „Czasopismo Kas Oszczędności” 1936, nr 6; M. Drybiński, Nowe prawo wekslowe i czekowe, „Bank” 1936, s. 45-51; Nowe prawo czekowe, „Śląskie Wiadomości Gospodarcze” 1936, nr 13/14; T. Kostecki, Wystawca czeku bez pokrycia w prawie czekowym 1936 r., „Głos Sądownictwa” 1936; W. Wedegis, O znaczeniu nowelizacji i prawa czekowego, „Przegląd Prawa Handlowego” 1937; Nowe Prawo Czekowe..., nr 13-14; B. Hełczyński, Dwudziestolecie polskiego ustawodawstwa gospodarczego, „Polska Gospodarcza” 1938, z. 46.

Zob. rozporządzenie Ministra Sprawiedliwości z dnia 19 listopada 1936 r. o niszczeniu odpisów protestów weksli i czeków (Dz. U. Nr 90, poz. 625); rozporządzenie Ministra Skarbu z dnia 25 listopada 1936 r. wydane w porozumieniu z Ministrem Sprawiedliwości o izbach rozrachunkowych (Dz. U. Nr 90, poz. 627). 
kowym. Dlatego wiele racji miał Adam Daniel Szczygielski, który stwierdził, że „nowelizacja prawa czekowego nie stanowi jedynie wygładzeń stylistycznych lub ułatwień interpretacyjnych, na jakich $\mathrm{w}$ większej części polega nowelizacja prawa wekslowego (nota bene dokonana jednocześnie z prawem czekowym) ${ }^{76}$, lecz $\mathrm{w}$ istocie swej jest całkowitem zrewidowaniem obecnie istniejącego systemu prawnego i zbudowaniem nowego systemu na nowych i trwałych podstawach"77.

Po zakończeniu drugiej wojny światowej prawo czekowe nie zostało uchylone ani nie zmieniono treści jego przepisów. Nawet wejście w życie nowego kodeksu karnego z 1969 r. nie zmieniło tego stanu, w odniesieniu do odpowiedzialności karnej za wystawienie czeku bez pokrycia ${ }^{78}$. Po prostu prawo czekowe zostało niejako wkomponowane do nowego systemu prawno-gospodarczego, a czek stanowił przede wszystkim środek zapłaty w stosunkach między jednostkami gospodarki uspołecznionej ${ }^{79}$. Zainteresowanie instytucją czeku nastąpiło po 1989 r., kiedy miała miejsce zmiana systemu gospodarczego w Polsce. Wiązały się z tym również zmiany $\mathrm{w}$ prawie bankowym, dotyczące operacji bankowych, zwłaszcza w zakresie czeków potwierdzonych i gwarantowanych ${ }^{80}$. Zmiany $\mathrm{w}$ polskim prawie czekowym, zresztą o charakterze porządkującym system prawny, nastąpiły dwukrotnie. Pierwszy raz z dniem wejścia w życie ustawy z dnia 6 czerwca 1997 r. przepisy wprowadzające kodeks karny ${ }^{81}$. Dotyczyło to nowej redakcji art. 61 prawa czekowego, a konkretnie sankcji karnych związanych z wystawieniem czeku bez pokrycia. Ostatnie zaś zmiany prawa czekowego zostały dokonane $\mathrm{z}$ chwilą wejścia w życie ustawy z dnia 10 marca $2006 \mathrm{r}$. o zmianie ustawy o wydawaniu Monitora Sądowego i Gospodarczego oraz

76 Przypis autora. Zob. Ustawa z dnia 28 kwietnia 1936 r. Prawo wekslowe (Dz. U. Nr 37, poz. 282).

77 A. D. Szczygielski, Zasady nowego polskiego prawa czekowego..., nr 29-30, s. 439.

78 Zob. art. V $\$ 2$ pkt 5 w związku z art. XIII pkt 1 i 3 ustawy z dnia 19 kwietnia 1969 r. Przepisy wprowadzające kodeks karny (Dz. U. Nr 13, poz. 95).

79 Szerzej: Z. Warman, Z aktualnych zagadnień obrotu czekowego, „Przegląd Ustawodawstwa Gospodarczego" 1953, nr 1; T. Szente, Prawo wekslowe i czekowe. Komentarz, Warszawa 1974, s. 121-124; S. Grzybowski, Czek, [w:] System Prawa Cywilnego, t. III, część 2: Prawo Zobowiązań - Część Szczegółowa (red. nacz. W. Czachórski), Wrocław - Warszawa - Kraków - Gdańsk 1976, s. 1050-1052.

80 Zarządzenia Prezesa Narodowego Banku Polskiego z dnia: 11 sierpnia 1989 r. w sprawie form i trybu przeprowadzania za pośrednictwem banków rozliczeń pieniężnych między osobami prawnymi oraz między tymi osobami i innymi podmiotami (Monitor Polski, Nr 27, poz. 219); 11 grudnia 1992 r. w sprawie form i trybu przeprowadzania rozliczeń pieniężnych za pośrednictwem banków (Monitor Polski, Nr 39, poz. 293); 29 maja 1998 r. w sprawie form i trybu przeprowadzania rozliczeń pieniężnych za pośrednictwem banków (Monitor Polski, Nr 21, poz. 320); zob. T. Komosa, Papiery wartościowe, „Przegląd Prawa Handlowego” 1995, nr 4 (opracowania monograficzne PPH), s. 15-20; J. Cybulski, Prawie wszystko o czekach, „Przegląd Ustawodawstwa Gospodarczego” 1990, nr 10.

81 Dz. U. Nr 88 , poz. 554 ; art. $5 \$ 2$ pkt 4 ustawy. 
o zmianie niektórych innych ustaw ${ }^{82}$. Dotyczyły postępowania amortyzacyjnego, w przypadku zaginionego czeku, a in concreto określenia sądu, jako właściwego do uznania czeku za umorzony - sąd rejonowy, oraz dziennika właściwego do umieszczania przez sąd wezwania skierowanego do posiadacza zaginionego czeku - Monitor Sądowy i Gospodarczy.

\section{Podsumowanie}

Unifikacja, a co za tym idzie pierwsza kodyfikacja, polskiego prawa czekowego związana była z przeprowadzoną w latach 20. reformą gospodarczą. Instytucja czeku miała stanowić jeden z jej elementów, w zakresie obrotu bezgotówkowego. Uważano bowiem, iż jedną z właściwości czeku jest funkcja antyinflacyjna. Dlatego wejście w życie rozporządzenia Prezydenta Rzeczypospolitej o prawie czekowem z 1924 r. miało służyć osiągniętej stabilizacji walutowej. Rozporządzenie było oparte na: dość luźnych rezolucjach sformułowanych w Hadze w 1912 r.; zaborczych ustawach czekowych, a nade wszystko na własnych rozwiązaniach Komisji Kodyfikacyjnej. Prawo czekowe z 1924 r. spotkało się z ostrą krytyką, przy czym dopiero praktyka ujawniła jego istotne braki. Dotyczyły one w szczególności wykorzystywanej w obrocie gospodarczym funkcji kredytowej czeku - tzw. czeki postdatowane i in blanco, oraz niewłaściwego unormowania odpowiedzialności za wystawienie czeku bez pokrycia. W pierwszym wypadku takie czeki określano mianem „weksli z żyrem prokuratora”, w drugim zaś stosowanie sankcji miało charakter iluzoryczny, ze względu na nieostre przesłanki zawarte w rozporządzeniu. W ten sposób sądy powszechne były bezradne wobec zjawiska czeków blankowych ${ }^{83}$.

Przeprowadzona na początku lat 30. międzynarodowa unifikacja prawa czekowego w Genewie miała już bezpośredni wpływ na kodyfikację polskiego prawa czekowego w 1936 r. Państwo polskie uczestnicząc, a następnie ratyfikując trzy konwencje genewskie, zobowiązało się dostosować do nich swoje wewnętrzne prawo czekowe. W ten sposób polskie prawo czekowe należy do rodziny prawa konwencyjnego. Dlatego zmiany w jego postanowieniach są w praktyce trudne do przeprowadzenia. Co zresztą można było zauważyć po 1945 r. w zmienionej

82 Dz. U. Nr 73, poz. 501; art. 3 ustawy.

83 Szerzej: E. Stankiewicz, Odpowiedzialność wystawcy czeku, „Miesięcznik Prawa Handlowego i Wekslowego” 1929, nr 1; K. Janowski, Pokrycie czekowe, „Miesięcznik Prawa Handlowego i Wekslowego” 1929, nr 1; K. Kl., Plaga czeków bez pokrycia. O zaostrzenie prawa czekowego w Polsce, „,Kurjer Łódzki” 10 maja 1931 (przedruk: „Gazeta Bankowa” 1931, nr 11); L. Laub, Karalność wystawienia czeku bez pokrycia (Uwagi o artykule 51 polskiego prawa czekowego), „Nowa Palestra” 1934, nr 2. 
rzeczywistości prawno-gospodarczej. Współczesne prawo czekowe, poza nieistotnymi zamianami o charakterze głównie redakcyjnym, stanowi stabilny system, który zawdzięcza swoją trwałość kodyfikacji dokonanej w drugiej połowie lat 30. ubiegłego stulecia. 